\title{
The use of amiloride hydrochloride in the correction of hypokalaemic alkalosis induced by diuretics
}

\author{
A. C. AntClifF \\ M.B., B.S. \\ Chemical Pathologist \\ M. Hamilton \\ M.D., F.R.C.P. \\ Consultant Physician
}

\author{
D. G. BEEVERS \\ M.B., M.R.C.P. \\ Medical Registrar
}

J. E. HARPUR

M.B., B.S.

Research Registrar

Chelmsford Group of Hospitals

\section{Summary}

Amiloride hydrochloride is a very potent drug for correcting the profound hypokalaemia and metabolic alkalosis that is induced by thiazide and other diuretics. No potassium supplements are necessary.

\section{Introduction}

Amiloride hydrochloride/MSD (Midamor) is a guanidine diuretic which possesses modest natriuretic and diuretic properties combined with a marked ability to reduce urinary potassium loss. No enzymatic basis has been found for its action. It acts predominantly on the distal nephron and a possible mode of action is on the contraluminal sodiumpotassium pump of the distal tubular cell (Wilson $e t$ al., 1966). It therefore enhances the natriuretic action of thiazides, but prevents the potassium loss incurred by these without impairing the glomerular filtration rate (Singh et al., 1967). Amiloride has also been claimed to have a mild non-postural hypotensive effect (Gombos, Freis \& Moghadam, 1966; Paterson, Dollery \& Harlam, 1968). Action starts within $4 \mathrm{hr}$ of oral administration and lasts up to 48 hr (Moukheibir \& Kirkendall, 1965).

\section{Patients and methods}

Nineteen patients with a long standing hypokalaemia whilst on treatment with thiazide diuretics for hypertension or congestive cardiac failure were specially selected. Two started treatment as inpatients and the remainder as out-patients. They were all receiving large doses of potassium supplements (Table 1) which were then discontinued on commencing amiloride hydrochloride, generally $10-15 \mathrm{mg} / \mathrm{day}$. Routine clinical examinations were performed and the blood pressure was recorded at each subsequent visit to the clinic.

Potassium and total carbon dioxide levels were measured after 1 week in some cases, but always within the first month and then at regular intervals.
A heparinized sample of blood was used for the estimation. The plasma potassium was determined by flame photometry and the bicarbonate (measured as the total carbon dioxide content) on the AutoAnalyzer. The blood urea was also recorded regularly.

The period of follow-up is generally from 2 to 5 months in this survey, but the majority of patients are still continuing on the drug. This is, therefore, a preliminary communication and the long-term value of the drug is still under assessment.

\section{Results}

Table 1 compares the average serum potassium and total carbon dioxide whilst on potassium supplements with the final values for these whilst on amiloride hydrochloride. Figure 1 also demonstrates that there was a considerable rise in the serum potassium (mean rise $0.541 \mathrm{mEq} / \mathrm{l}$ ). Figure 2, similarly, shows a marked fall in total $\mathrm{CO}_{2}$ (mean fall $2.661 \mathrm{mEq} / \mathrm{l})$. The shift of the serum potassium and total $\mathrm{CO}_{2}$ is also shown in Fig. 3. These figures include all the values for the serum potassium and total $\mathrm{CO}_{2}$ obtained before and after treatment with amiloride $(\bar{x}=$ mean value and $\sigma=$ the standard deviation from the mean in all figures).

In the majority of patients there was no rise in the blood urea. In Case 19 a high blood urea had previously been recorded on some occasions before treatment and this showed no deterioration afterwards. One other developed a high blood urea due to accelerated hypertension and cardiac failure.

There was no significant change in the supine blood pressure after changing to amiloride.

One patient discontinued the drug after 6 days (Case 10) and does not appear in the results as he developed severe nausea with 'coffee ground' vomiting. This led to dehydration necessitating intravenous fluid replacement. One other patient (Case 2) had to discontinue the drug after a few 
TABLE 1.

\begin{tabular}{|c|c|c|c|c|c|c|c|c|}
\hline \multirow[b]{2}{*}{$\begin{array}{c}\text { Case } \\
\text { no. }\end{array}$} & \multicolumn{2}{|c|}{ Serum $\mathrm{K}^{+}(\mathrm{mEq} / \mathrm{l})$} & \multicolumn{2}{|c|}{ Serum $\mathrm{HCO}_{3}-(\mathrm{mEq} / \mathrm{l})$} & \multirow[b]{2}{*}{$\begin{array}{l}\text { Diuretic } \\
\text { (mg/day) }\end{array}$} & & \multirow{2}{*}{$\begin{array}{c}\text { Daily } \\
\text { no. of } \\
\text { potassium } \\
\text { tablets }\end{array}$} & \multirow[b]{2}{*}{$\begin{array}{l}\text { Amiloride } \\
\text { (mg/day) }\end{array}$} \\
\hline & $\begin{array}{l}\text { With } \\
\text { potassium } \\
\text { supplement }\end{array}$ & $\begin{array}{l}\text { With } \\
\text { amiloride }\end{array}$ & $\begin{array}{c}\text { With } \\
\text { potassium } \\
\text { supplement }\end{array}$ & $\begin{array}{c}\text { With } \\
\text { amiloride }\end{array}$ & & & & \\
\hline 1 & $3 \cdot 2$ & $3 \cdot 2$ & 31 & 27 & Chlorthalidone & 100 & 8 & $15-20$ \\
\hline 2 & $3 \cdot 1$ & $3 \cdot 5$ & 34 & 34 & Bendrofluazide & 5 & 3 & $10-5$ \\
\hline 3 & 2.9 & $3 \cdot 5$ & 33 & 29 & Polythiazide & 10 & 8 & $10-15$ \\
\hline 4 & $2 \cdot 8$ & $3 \cdot 4$ & 31 & 29 & Hydroflumethiazide & $100^{*}$ & 4 & 10 \\
\hline 5 & $3 \cdot 0$ & $3 \cdot 2$ & 34 & 32 & Hydroflumethiazide & 200 & 6 & $15-20$ \\
\hline 6 & $3 \cdot 0$ & 3.9 & 33 & 29 & Frusemide & 80 & 8 & 15 \\
\hline 7 & $3 \cdot 8$ & $4 \cdot 2$ & 31 & 29 & Hydroflumethiazide & $200 \dagger$ & 6 & $15-10$ \\
\hline 8 & $2 \cdot 9$ & $3 \cdot 5$ & 30 & 30 & Hydrochlorothiazide & 100 & 8 & 15 \\
\hline 9 & $3 \cdot 2$ & $4 \cdot 0$ & 33 & 28 & $\begin{array}{l}\text { Frusemide } \\
\text { Ethacrynic acid }\end{array}$ & $\begin{array}{l}80 \\
50\end{array}$ & 3 & 15 \\
\hline 10 & $3 \cdot 6$ & $4 \cdot 2$ & 31 & 30 & Hydrochlorothiazide & 200 & 6 & 10 \\
\hline 11 & $3 \cdot 1$ & $4 \cdot 3$ & 35 & 30 & Hydrochlorothiazide & 100 & 4 & 10 \\
\hline 12 & $3 \cdot 6$ & $4 \cdot 0$ & 33 & 32 & Hydroflumethiazide & 200 & 4 & $10-20$ \\
\hline 13 & $3 \cdot 3$ & $3 \cdot 2$ & 29 & 28 & Hydrochlorothiazide & 200 & 4 & $10-15$ \\
\hline 14 & $3 \cdot 2$ & 3.9 & 29 & 23 & Hydroflumethiazide & $200^{*}$ & 4 & 10 \\
\hline 15 & $3 \cdot 1$ & $3 \cdot 8$ & 34 & 30 & Hydroflumethiazide & $100-200$ & 2 & $5-10$ \\
\hline 16 & $2 \cdot 9$ & $3 \cdot 3$ & 32 & 30 & Hydroflumethiazide & 200 & 6 & 15 \\
\hline 17 & $3 \cdot 6$ & $3 \cdot 2$ & 32 & 29 & Hydroflumethiazide & $200^{*}$ & 4 & 15 \\
\hline 18 & $3 \cdot 2$ & $4 \cdot 2$ & 33 & 32 & Hydroflumethiazide & 200 & 4 & 15 \\
\hline 19 & $3 \cdot 1$ & $4 \cdot 8$ & 33 & 26 & Hydrochlorothiazide & 100 & 2 & $15-10$ \\
\hline
\end{tabular}

* 5 days in 7 .

$\dagger 6$ days in 7 .

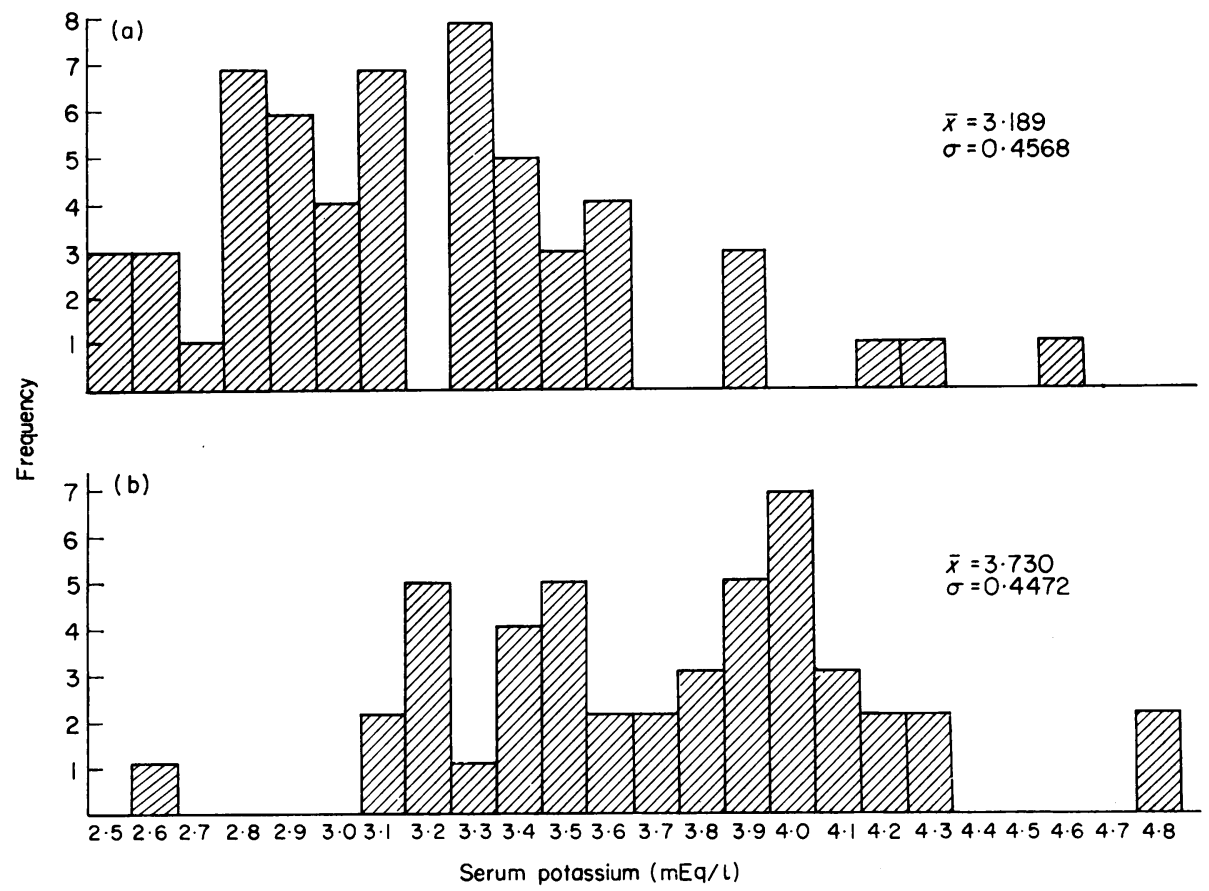

Fig. 1. The potassium levels whilst (a) on potassium supplements and (b) on amiloride. All observations on eighteen patients. 


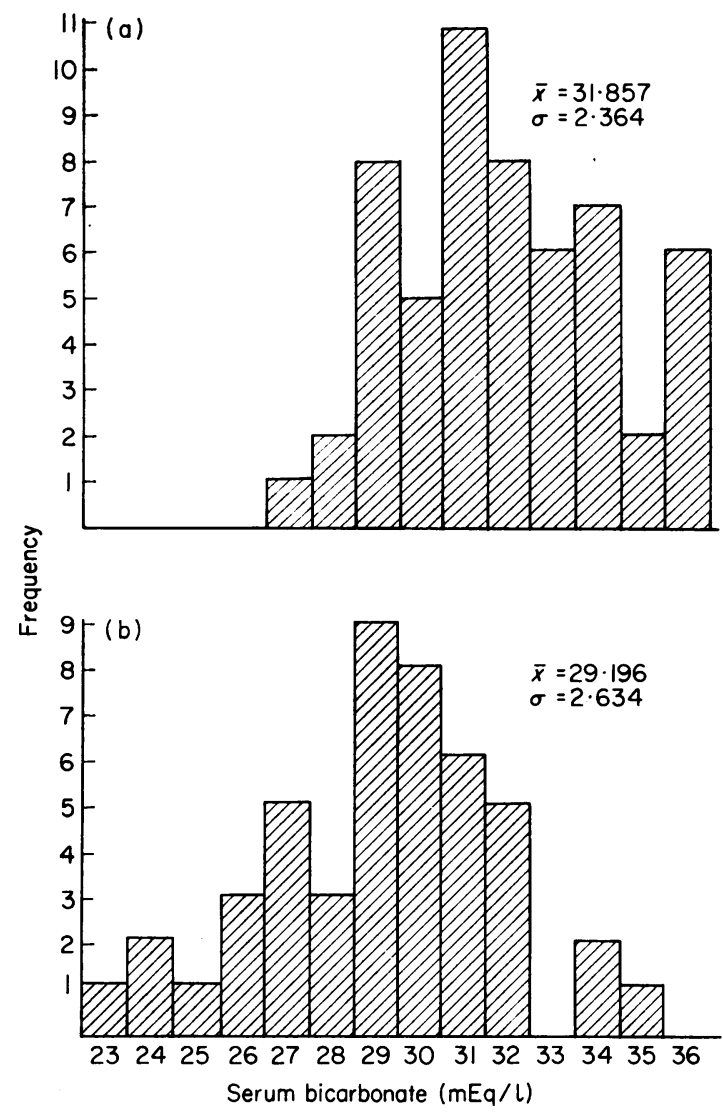

FIG. 2. The total carbon dioxide levels whilst (a) on potassium supplements and (b) on amiloride. All observations on eighteen patients.

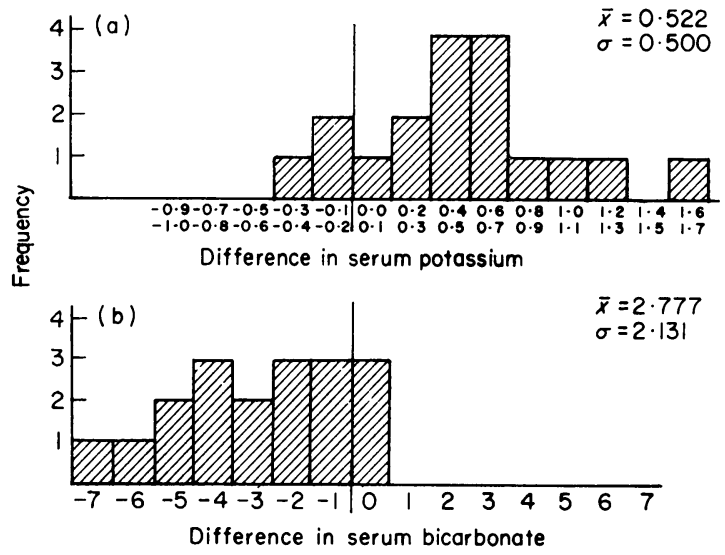

Fig. 3. The change in (a) the serum potassium (final level on amiloride minus average level on potassium supplements), and (b) total carbon dioxide levels whilst on amiloride. All observations on eighteen patients. weeks because of abdominal pain and diarrhoea developing after a period of subjective improvement. Another (Case 14) complained of transient nausea which did not require withdrawal of the drug.

\section{Discussion}

Thirteen patients showed a rise in their serum potassium within 3 weeks of starting amiloride which is demonstrated in Table 1 and in sixteen patients there was a fall in the total $\mathrm{CO}_{2}$. Figure 3 is a graphic representation of the change of the serum levels of potassium and total $\mathrm{CO}_{2}$ when established on amiloride: figures to the right of the line indicate a rise and those to the left a fall of the serum level. Thus it illustrates that the majority of serum potassium levels rose while the majority of total $\mathrm{CO}_{2}$ levels fell. As has already been stated, the patients stopped all administration of potassium supplements on starting amiloride.

TABLE 2.

\begin{tabular}{|c|c|c|c|c|}
\hline \multirow[b]{2}{*}{ Case no. } & \multicolumn{2}{|c|}{$\begin{array}{c}\text { With } \\
\text { potassium supplements }\end{array}$} & \multicolumn{2}{|c|}{ With amiloride } \\
\hline & ${ }^{*}$ Mean $\mathrm{K}^{+}$ & Final $\mathrm{K}^{+}$ & Initial $\mathrm{K}^{+}$ & ${ }^{*}$ Final $\mathrm{K}^{+}$ \\
\hline 1 & $3 \cdot 2$ & $3 \cdot 1$ & $4 \cdot 0$ & $3 \cdot 2$ \\
\hline 5 & 3.0 & $2 \cdot 8$ & $3 \cdot 5$ & $3 \cdot 2$ \\
\hline 13 & $3 \cdot 3$ & $3 \cdot 3$ & $3 \cdot 2$ & $3 \cdot 2$ \\
\hline 16 & $2 \cdot 9$ & $2 \cdot 8$ & $3 \cdot 3$ & $3 \cdot 3$ \\
\hline 17 & $3 \cdot 6$ & $3 \cdot 3$ & $3 \cdot 6$ & $3 \cdot 2$ \\
\hline
\end{tabular}

*Figures used for comparison in Table 1.

Table 2 shows a more detailed analysis of the serum $\mathrm{K}^{+}$in the patients in whom the potassium did not change or fell. The mean serum $\mathrm{K}^{+}$on potassium supplements, which reflects the values over a period of at least 1 year, is sometimes higher than the final serum $\mathrm{K}^{+}$at the time of changing to amiloride, as in Case 17. The decision to substitute amiloride was naturally taken only on the basis of the final serum $\mathrm{K}^{+}$level whilst on potassium suplement. In two cases (Cases 1 and 5) the initial $\mathrm{K}^{+}$ on amiloride is considerably higher than the final value on potassium supplement. The fall which then followed indicates that these two cases needed an increased dose of amiloride. Case 16 had only been on the drug for a relatively short period of time, but shows a definite rise in serum $\mathrm{K}^{+}$from the final value on slow $\mathrm{K}$. Case 13 does not show a rise at any stage, but was only on $10 \mathrm{mg}$ of amiloride when the last serum $\mathrm{K}^{+}$was measured. No patient received more than $20 \mathrm{mg}$ of amiloride daily.

It was noted that there was a fall of the total $\mathrm{CO}_{2}$ to normal values in practically every case, and that none showed a rise of total $\mathrm{CO}_{2}$, indicating that amiloride corrects the metabolic alkalosis produced by thiazides as well as correcting the hypokalaemia. It is possible that the total $\mathrm{CO}_{2}$ gives a more accurate 
assessment of the total potassium content of the body than does a simple measurement of the serum potassium.

It has also been noted that a rise of serum $\mathrm{K}^{+}$can occur very quickly (within 2 days) and it may be that this large rise is only a temporary effect during the initial phase of maximum potassium sparing (Surveyor \& Saunders, 1968). This seems to be much more marked in patients receiving amiloride alone as the total body potassium presumably is so grossly depleted on treatment with thiazides that the potassium has much further to rise before reaching dangerous levels. The serum $\mathrm{K}^{+}$must therefore be closely monitored while on amiloride and very close supervision is essential in patients with impaired renal function.

Gastrointestinal side effects occurred in three out of nineteen cases. Diarrhoea has already been noted by Surveyor \& Saunders (1968). Singh et al. (1967) have noted that severe nausea can occur while on the drug especially when combined with other diuretics (Paterson et al., 1968).

None of our patients, nine of whom were already on potent hypotensive agents such as bethanidine or methyldopa, showed any change in blood pressure after starting amiloride (Gombos et al., 1966; Paterson et al., 1968).

Spironolactone and triamterene have also been used in conjunction with other diuretics on account of their potassium-retaining properties. The long latent period of spironolactone is sometimes a disadvantage and it is ineffective in the presence of renal failure. Gynaecomastia may be troublesome (Senewiratne \& Sherlock, 1968), and it is not always effective without additional $\mathrm{K}^{+}$supplement (Rosse, 1961). Triamterene has a shorter latent period but a rise in blood urea has been noted (Ginsberg, Saad \& Gabuzda, 1964) especially when given in combination with a benzothiadiazine diuretic (Shaldon \& Ryder, 1962).

Although no side-effects from hypokalaemia have been noted in these patients, it is known that this is a potentially dangerous condition, especially if the patient is on digitalis therapy: furthermore a dangerous hypokalaemia can suddenly be precipitated by a further drop of the serum potassium, which can follow for example a gastrointestinal loss as in epidemic diarrhoea.

\section{Acknowledgment}

We would like to thank The Chelmsford Medical Education and Research Trust for financial and secretarial help.

\section{References}

Ginsberg, D.J., SaAd, A. \& Gabuzada, G.J. (1964) Metabolic studies with the diuretic triamterene in patients with cirrhosis and ascites. New England Journal of Medicine, 271, 1229.

Gombos, E.A., Freis, E.D. \& Moghadam, A. (1966) Effects of MK-870 in normal subjects and hypertensive patients. New England Journal of Medicine, 275, 1215.

Moukheibir, N.W. \& Kirkendall, W.M. (1965) Effect of amidramizide (MK870) on electrolyte and water balance in patients with cirrhosis of liver. Clinical Research, 13, 425.

Rosse, E.J. (1961) Importance of potassium supplements during the use of spironolactone and thiazide diuretics. British Medical Journal, 1, 1508.

Paterson, J.W., Dollery, C.T. \& Haslam, R.M. (1968) Amiloride hydrochloride in hypertensive patients. British Medical Journal, 1, 422.

Senewiratne, B. \& Sherlock, S. (1968) Amiloride ('MK870') in patients with ascites due to cirrhosis of the liver. Lancet, 1, 120.

Shaldon, S. \& RYDER, J.A. (1962) Use of a pteridine diuretic (triamterene) in treatment of hepatic ascites. British Medical Journal, 2, 764.

Singh, B.N., Richmond, D.E., Wilson, J.D., Simmonds, H.A. \& NoRTH, J.D.K. (1967) Evaluation of MK-870: a new potassium-sparing diuretic. British Medical Journal, 1, 143.

Surveyor, I. \& Saunders, R.A. (1968) Amiloride and plasma-potassium. Lancet, ii, 516.

Wilson, J.D., Richmond, D.E., Simmonds, H.A. \& North, J.D.K. (1966) MK 870: A new potassium-sparing diuretic. New Zealand Medical Journal, 65, 505. 